\title{
White tea (Camellia sinensis) extract reduces oxidative stress and triacylglycerols in obese mice
}

\author{
Extrato de chá branco reduz extresse oxidativo e triacilglicerois em camundongos obesos \\ Lílian Gonçalves TEIXEIRA ${ }^{1 \star}$, Priscilla Ceci LAGES ${ }^{1}$, Tatianna Lemos JASCOLKA ${ }^{2}$, \\ Edenil Costa AGUILAR ${ }^{1}$, Fabíola Lacerda Pires SOARES ${ }^{2}$, Solange Silveira PEREIRA², \\ Nathalia Ribeiro Mota BELTRÃO ${ }^{1}$, Rafael de Oliveira MATOSO ${ }^{1}$, André Márcio do NASCIMENTO², \\ Rachel Oliveira de CASTILHO², Jacqueline Isaura Alvarez LEITE ${ }^{1}$
}

\begin{abstract}
White tea is an unfermented tea made from young shoots of Camellia sinensis protected from sunlight to avoid polyphenol degradation. Although its levels of catechins are higher than those of green tea (derived from the same plant), there are no studies addressing the relationship between this tea and obesity associated with oxidative stress. The objective of this study was to evaluate the effect of white tea on obesity and its complications using a diet induced obesity model. Forty male C57BL/6 mice were fed a high-fat diet to induce obesity (Obese group) or the same diet supplemented with $0.5 \%$ white tea extract (Obese + WTE) for 8 weeks. Adipose tissue, serum lipid profile, and oxidative stress were studied. White tea supplementation was not able to reduce food intake, body weight, or visceral adiposity. Similarly, there were no changes in cholesterol rich lipoprotein profile between the groups. A reduction in blood triacylglycerols associated with increased cecal lipids was observed in the group fed the diet supplemented with white tea. White tea supplementation also reduced oxidative stress in liver and adipose tissue. In conclusion, white tea extract supplementation (0.5\%) does not influence body weight or adiposity in obese mice. Its benefits are restricted to the reduction in oxidative stress associated with obesity and improvement of hypertriacylglycerolemia.

Keywords: high-fat diet; obesity; oxidative stress; white tea; Camellia sinensis.
\end{abstract}

\section{Resumo}

O chá branco é um chá não fermentando feito a partir de brotos jovens da Camellia sinensis protegidos da luz solar para evitar a degradação de polifenóis. Embora os níveis de catequinas sejam mais elevados que os do chá verde (mesma planta), nenhum estudo foi realizado sobre estresse oxidativo relacionado à obesidade. Nosso objetivo foi avaliar o efeito do chá verde na obesidade e suas complicações, usando um modelo de obesidade induzida por dieta. Quarenta camundongos C57BL/6 machos foram alimentados com dieta hiperlipídica para indução da obesidade ou mesma dieta suplementada com $0,5 \%$ de extrato de chá branco durante 8 semanas. Foram estudadoso tecido adiposo bem como o perfil lipídico e o estresse oxidativo. A suplementação com chá branco não foi capaz de reduzir a ingestão alimentar, peso corporal ou adiposidade visceral. De forma similar, não foram encontradas diferenças no perfil de lipoproteínas ricas em colesterol. Uma redução de triacilgliceróis sanguíneos, associada ao aumento de lipídios cecais, foi observada no grupo suplementado com chá branco. A suplementação também reduziu o estresse oxidativo no fígado e tecido adiposo. Em conclusão, suplementação com extrato de chá branco (0,5\%) não interfere no peso corporal ou adiposidade em camundongos obesos. Seus benefícios são restritos à redução do estresse oxidativo associada à obesidade e melhora da hipertrigliceridemia.

Palavras-chave: dieta hiperlipídica; obesidade; estresse oxidativo; chá branco; Camellia sinensis.

\section{Introduction}

Obesity is a disease involving genetic, endocrine, and behavioral factors, which include a diet rich in carbohydrate and fat and sedentary lifestyle. Obesity is also associated with increased oxidative stress (FURUKAWA et al., 2004). It has been proposed that hyperglycemia, mitochondrial dysfunction, and enzymatic imbalance of redox system are involved in the cellular production of reactive oxygen species (ROS) in obesity (PARK; CHUNG; KIM, 2007). This disease also induces secretion of proinflammatory adipokines, such as leptin, resistin, TNFa, IL-6,
MCP-1, and decreases adiponectin secretion. This feature leads to increased pro-inflammatory genes transcription, activates NADPH oxidase dependent reactions, causes oxidation of lipoproteins, enhances insulin resistance, which culminates in atherosclerosis, type 2 diabetes mellitus, and metabolic syndrome. (FURUKAWA et al., 2004).

White tea is an unfermented tea made from young shoot of Camellia sinensis protected from sunlight to avoid the degradation of its polyphenols (ALCAZAR et al., 2007). Similarly to green 
tea, white tea has been used to reduce oxidative stress and to treat obesity and associated diseases. However, most studies using white tea investigated its composition (ALCAZAR et al., 2007; MALINOWSKA et al., 2008; UNACHUKWU et al., 2010; VAN DER HOOFT et al., 2012), its antitumorigenic effect (ANGER; PETRE; CRANKSHAW, 2005; KUMAR et al., 2012; WANG et al., 2008), or its antioxidant action (ALMAJANO; VILA; GINES, 2011; CALZUOLA; GIANFRANCESCHI; MARSILI, 2006; KOUTELIDAKIS et al., 2009; LOPEZ; CALVO, 2011; PEREZ-JIMENEZ et al., 2011; 2012; SEERAM et al., 2008; THRING; HILI; NAUGHTON, 2009, 2011). Nonetheless, despite its popular use, there are no in vivo studies relating white tea and obesity associated with oxidative stress. Thus, the effect of the white tea extract (WTE) supplementation on the development of obesity was evaluated using a high-fat diet induced obesity model.

\section{Materials and methods}

Preparation of the white tea extract: white tea extract was prepared by Nanjing Wellchem Enterprise Co. LTDA as follows: the sprouts of the Camellia sinensis leaves were dried under room temperature $\left(25-35^{\circ} \mathrm{C}\right)$ by natural ventilation and processed to obtain flakes of 40-60 mesh. The flakes were mixed in water, and the extract filtered and submitted to Vacuum Decompression Concentration. After filtration, the extract was mixed with ethyl acetate and washed with water. The ethyl acetate extract was recovered and again submitted to vacuum concentration following by sterilization at high temperatures. Finally, the extract was dried, mixed, analyzed, and packaged.

White tea extract purification and analytical conditions: Aqueous extract was purified by liquid-liquid extraction using an ethyl acetate:butanol:2-propanol:water (3.5:0.5:1.0:4.5) solvent system, which was mechanically homogenized in duplicate for 30 minutes in a stoppered flask. An aliquot of the aqueous extract $(250 \mathrm{mg}$ ) was accurately weighed, transferred to a separation funnel, and extracted with the solvent system into organic and aqueous fractions. After separation, organic and aqueous fractions were separately evaporated under air stream $\left(40^{\circ} \mathrm{C}\right)$. The dry samples were stored at $4{ }^{\circ} \mathrm{C}$, and the percentage of each fraction in relation to the initial material was calculated. The HPLC analysis were carried out using a HP1100 system (Agilent, Santa Clara, USA) coupled to a quaternary pump, an auto sampler, and a programmable ultraviolet photodiode array detector (UV/DAD). An HP Chem Station (for LC 3D System) software (Rev. B.02.01-SR2[260] 2001-2006) was used to analyze data. Separation was performed using a reversed-phase C18pre-column (XDB Zorbax ${ }^{\circledR}, 4 \times 4$ mm I.D.; $5 \mu \mathrm{m}$, Agilent, Santa Clara, USA) attached to a C18 column (LiChrospher ${ }^{\oplus} 100$, $250 \times 4 \mathrm{~mm}$ I.D.; $5 \mu \mathrm{m}$, Merck, Darmstadt, Germany) at $40{ }^{\circ} \mathrm{C}$. The injection volume was $10 \mu \mathrm{L}$, and it was monitored at $\lambda 210 \mathrm{~nm}$. UV spectra were recorded on-line for peak identification from $\lambda 190 \mathrm{~nm}$ to $400 \mathrm{~nm}$. The mobile phase was composed of $0.1 \%$ phosphoric acid (solution A) and acetonitrile $0.1 \%$ phosphoric acid (solution B). The linear gradient was from A-B $(95: 5, v / v)$ to A-B $(60: 40, v / v)$ in 60 minutes, followed by cleaning and reconditioning the column. For the preparation of standards, approximately $5 \mathrm{mg}$ of each reference substance
(HPLC grade, catechin (C), gallocatechin (GC), epigallocatechin (EGC), and epigallocatechin gallate (EGCG)) were accurately weighed in $5 \mathrm{~mL}$ volumetric flasks. The standards were dissolved in methanol $(3 \mathrm{~mL})$ and the volume was adjusted to $5 \mathrm{~mL}$ with the same solvent. These standard solutions were stored at -3 to $-5^{\circ} \mathrm{C}$ (NASCIMENTO; CASTILHO; VIANNA-SOARES, 2009).

Animals and diet: Male C57BL/6 mice were kept in collective cages (five animals per cage) with free access to diet and water with a controlled dark/dark cycle in a temperature controlled room. The project was approved by the Ethics Committee of Animal Experiments of Federal University of Minas Gerais (protocol 116/2009). The diet induced obesity model had been previously confirmed by a pilot experiment in which animals were fed chow or high-fat diet, as suggested by Akagiri (AKAGIRI et al., 2008).

The animals were allocated into Obese group $(n=20)$, receiving high-fat diet and white tea obese group (Obese + WTE; $\mathrm{n}=20$ ), receiving the same high-fat diet supplemented with $0.5 \%$ of WTE for 8 weeks. Body weight and food and water intake were determined weekly. After 8 experimental weeks and fasting for 12 hours, all animals were anesthetized and euthanized by exsangination and cervical dislocation.

Perigonadal adipose tissue analysis. Perigonadal adipose tissue was removed, dried in filter paper, weighed, and used for the determination of visceral adiposity, which was calculated as follows: perigonadal adipose tissue $(\mathrm{g}) /$ final body weight (g) $\times 100$.

For histological analysis, a sample of perigonadal adipose tissue was washed in PBS, fixed in Bouin's solution and ethanol, and included in paraffin. Samples of $7 \mu \mathrm{m}$-thick were obtained in microtome, stained with hematoxylin-eosin, and analyzed using an ImageProPlus software (Image-Pro Plus Software, Bethesda Maryland - USA). The area of adipocytes of each animal was determined by the mean of 100 adipocyte areas.

The sections of adipose tissue were also used for the counting of crown-like structures. The result was expressed as the mean of structures seen in 10 fields per mouse. Macrophage infiltration in adipose tissue was measured indirectly by measuring the activity of the enzyme $\mathrm{N}$-acetyl-glucosaminidase (NAG), as previously described (BAILEY, 1988).

Blood measurements: Samples of blood were collected during the sacrifice without anticoagulant for lipid profile determination or using glucose determination specific anticoagulant (EDTA, 6 g.L $\mathrm{L}^{-1}$ and potassium fluoride, $12 \mathrm{~g} . \mathrm{L}^{-1}$, Glistab, Labtest). After that, serum and plasma were obtained after centrifugation at $6.000 \mathrm{rpm}$ for 5 minutes. Total cholesterol, HDL cholesterol (HDL-c), and triacylglycerols as well as plasma glucose concentration were determined by enzymatic colorimetric tests (Labtest, Brazil) in a 96-well microplate, as previously described (FAZIO et al., 1997). The non-HDL cholesterol fraction was calculated by the difference between total cholesterol and HDL-c. The oral glucose tolerance and insulin sensitivity tests were performed as previously described (SANTOS et al., 2008). 
Serum conjugated diene: The kinetics of copper-induced lipid oxidation of plasma preparations (diluted 100-fold in PBS) was monitored at $245 \mathrm{~nm}$ at $37^{\circ} \mathrm{C}$ for 4 hours. The final concentration of copper was $30 \mu \mathrm{mol} . \mathrm{L}^{-1}$ (SCHNITZER et al., 1998). Lag-time (t lag) phase was determined graphically by the intercept of the tangents to the slow and fast increase of the diene absorption (GIESEG; ESTERBAUER, 1994; PINCHUK; LICHTENBERG, 2002).

Anti-ox-LDL antibodies: Blood samples from healthy volunteers were collected in tubes containing EDTA and were centrifuged at $3000 \mathrm{rpm}$ for 10 minutes at $4{ }^{\circ} \mathrm{C}$. LDL was isolated by sequential ultracentrifugation at $50,000 \mathrm{rpm}$ for 2.5 hours at $4{ }^{\circ} \mathrm{C}$ on a Sorvall Ultracentrifuge after density adjustment with potassium bromide using a $875 \mathrm{~T}$ rotor (CHUNG et al., 1986). Isolated LDL was dialyzed overnight against PBS, passed through an Acrodisc filter $(0.22 \mu \mathrm{m}$ pore size $)$, and stored under nitrogen in the dark at $4{ }^{\circ} \mathrm{C}$. The oxidation of LDL was performed (VAY et al., 2001), and the anti-native and oxidized LDL antibodies were determined by ELISA, as previously described (NARVANEN; ERKKILA; YLA-HERTTUALA, 2001). Anti-native LDL antibodies were used only as an internal control.

Briefly, the plates were coated with $100 \mu$ l.well ${ }^{-1}$ of nat-LDL $\left(10 \mu \mathrm{g} \cdot \mathrm{mL}^{-1}\right)$ or ox-LDL $\left(10 \mu \mathrm{g} \cdot \mathrm{mL}^{-1}\right)$, incubated overnight at $4{ }^{\circ} \mathrm{C}$, washed with PBS containing $0.05 \%$ Tween 20 , and blocked with PBS containing $1 \% \mathrm{BSA}\left(200 \mu \mathrm{l}\right.$.well $\left.{ }^{-1}\right)$. The plates were incubated for 3 hours with experimental sera dilutions (1:20 in PBS), washed, and then incubated for 2 hours at $37^{\circ} \mathrm{C}$ with HRP conjugated anti-human IgG diluted 1:20000 $\left(100 \mu\right.$ l.well $\left.^{-1}\right)$. After washing, color was developed by adding the OPD $\left(100 \mu\right.$ l.well $\left.{ }^{-1}\right)$. The reaction was stopped with $1 \mathrm{M} \mathrm{H}_{2} \mathrm{SO}_{4}$ diluted 1:20 in distilled water $\left(10 \mu\right.$ l.well $\left.{ }^{-1}\right)$. Absorbance was measured at $492 \mathrm{~nm}$ (Modelar Devices, Spectra Max Plus).

Lipid content was determined in samples of liver, perigonadal adipose tissue, and cecal content. Liver and perigonadal fat were removed, washed with saline solution, and dried in paper filter. Cecal content was dried in an oven at $60^{\circ} \mathrm{C}$. Lipid extraction was performed in all samples according to Folch (FOLCH, 1956).

The oxidative stress was determined in liver and adipose tissue by the formation of products of lipid peroxidation by TBARS technique in 96-well microplates, as described by Wallin (WALLIN et al., 1993), and hydroperoxide contents were obtained as previously described (BANERJEE, 2002). The activity of antioxidant enzymes superoxide dismutase (SOD) and catalase was determined as described by Dieterich et al. (2000) and Nelson and Kiesow (1972), respectively, after protein determination .using the method of Lowry et al. (1951).

The liver function was determined by the measurement of liver gamma glutamyl transferase (GGT) using a commercial kit (Labtest, Brazil) based on GGT kinetics.

Statistical methods: Data are shown as mean \pm standard error (SEM) or median, minimum-maximum and analyzed using a software Prism (GraphPad Software, San Diego California - USA), version 5.0. Grubbs' test was used to detect outliers. To check the normality of the sample tests, D'Agostino and Pearson and Kolmogorov-Smirnov tests were used. Student $\mathrm{t}$ test and Mann Whitney were used to compare differences between the experimental groups. P values $<0.05$ were considered statistically significant.

\section{Results}

The white tea extract analysis confirmed that epigallocatechin gallate (EGCG) is the main active compound of non-fermented tea $(19,63 \%)$ made from Camellia sinensis, followed by epigallocatechin (EGC; 3.25\%), gallocatechin (GC; 1.28\%), and catechin $(\mathrm{C} ; 0.71 \%)$ which were also found in the extract.

Food and water intake were not affected by WTE intake (Table 1). As a result, body weight was similar between the groups (Table 1). Adipose tissue characteristics were also unaltered, regardless of WTE intake. Perigonadal (visceral) fat relative weight, adipocyte area, lipid content, macrophage infiltration (measured by NAG activity) as well as number of macrophage forming crown like structure were all similar between the groups (Figure 1 and Table 2).

Regarding glucose homeostasis, WTE supplementation did not cause any alteration in fasting glycemia, oral glucose tolerance, and insulin sensibility tests (Table 3).

Lipid profile was also analyzed. WTE supplemented mice presented lower concentrations of serum triacylglycerols than the control animals although total and fractions cholesterol was kept unaltered (Table 3). To assess whether the reduction

Table 1. Body weight, food, and water (tea) intake and adiposity of mice receiving high-fat diet (Obese group) or high-fat diet supplemented with white tea extract (0.5\%, Obese + WTE group) for eight weeks. ${ }^{1}$

\begin{tabular}{lrc}
\hline \multicolumn{1}{c}{ Characteristics $^{2}$} & \multicolumn{1}{c}{ Obese } & Obese + WTE \\
\hline Final body weight $(\mathrm{g})$ & $16.82 \pm 0.68$ & $15.84 \pm 0.65$ \\
Food intake (g/mice/day) & $16.34 \pm 0.70$ & $18.08 \pm 1.00$ \\
Water (tea) intake (mL/mice/day) & $4.57 \pm 0.17$ & $4.13 \pm 0.11$ \\
Final body weight (g) & $32.41 \pm 0.70$ & $31.05 \pm 0.99$ \\
Perigonadal fat (\% of body weight) & $3.40 \pm 0.59$ & $3.88 \pm 0.47$ \\
$\gamma$ Glutamyl transpeptase (liver) & $8.66 \pm 1.47$ & $6.50 \pm 1.04$ \\
\hline
\end{tabular}

${ }^{1}$ Values are mean \pm SEM. ${ }^{2}$ Tukey, $\mathrm{p} \leq 0.05 . \mathrm{n}=8$ animals per group.

Table 2. Perigonadal adipose tissue characteristics in mice receiving high fat diet (Obese group) or high fat diet supplemented with white tea extract (0.5\%, Obese+WTE group) for eight weeks. ${ }^{1}$

\begin{tabular}{|c|c|c|}
\hline Characteristics $^{2}$ & Obese & Obese+WTE \\
\hline Perigonadal fat (\% of body weight) & $3.40 \pm 0.59$ & $3.88 \pm 0.47$ \\
\hline Adipocyte area $\left(\mu \mathrm{m}^{2}\right)$ & $9791 \pm 1257$ & $10043 \pm 1009$ \\
\hline Triacylglycerol content (mg/g tissue) & $164.9 \pm 8.4$ & $151.7 \pm 6.5$ \\
\hline NAG activity (UA/100 mg tissue) & $0.098 \pm 0.011$ & $0.105 \pm 0.011$ \\
\hline $\begin{array}{l}\text { Crown like structure } \\
\text { (number/10 fields) }\end{array}$ & $0.44 \pm 0.05$ & $0.32 \pm 0.05$ \\
\hline $\begin{array}{l}\text { MDA concentration } \\
\left(\mu \mathrm{mol} \times \mathrm{g}^{-1} \text { protein }\right)\end{array}$ & $0.23 \pm 0.03$ & $0.14 \pm 0.04^{\star}$ \\
\hline $\begin{array}{l}\text { Hydroperoxide concentration } \\
\left(\mu \mathrm{mol} \times \mathrm{g}^{-1} \text { protein }\right)\end{array}$ & $13.56 \pm 3.14$ & $11.41 \pm 4.44$ \\
\hline SOD activity $\left(\mathrm{U} \times \mathrm{mg}^{-1}\right.$ protein $)$ & $6.84 \pm 1.42$ & $5.85 \pm 1.12$ \\
\hline $\begin{array}{l}\text { Catalase activity } \\
\left(\Delta \mathrm{E} \min ^{-1} \times \mathrm{mg}^{-1} \text { protein }\right)\end{array}$ & $0.88 \pm 0.21$ & $1.67 \pm 0.37$ \\
\hline
\end{tabular}


in serum triacylglycerols was related to changes in the lipid absorption, the lipid content in the caecum and liver was analyzed. The results show that the animals in the WTE group excreted more lipids compared to those in the control group. However, TAG and TC as well as hepatic total lipids were not different, regardless of WTE intake (Figure 2).

Obesity is related to increased oxidative stress caused by the adipocyte enlargement and macrophage infiltration. To evaluate whether white tea extract is able to reduce the pro-oxidative state observed in obese subjects, malondialdehyde (MDA) and hydroperoxide formation in adipose tissue, liver, and kidney were measured. A reduction in MDA concentration in the adipose tissue after white tea extract supplementation was observed. However, no differences were observed in hydroperoxide concentration in this site. On the other hand, the effect of white tea was more prominent in liver, with a significant reduction in oxidative stress as assessed by both MDA and hydroperoxide concentrations. No effect was seen in the kidney. With regard to the activity of antioxidant enzymes, white tea did not change the activity of both SOD and catalase in liver and adipose tissue (Table 3, Figure 3).

Table 3. Glucose homeostasis tests and lipid profile of C57BL/6 obese mice receiving high-fat diet (Obese group) or high fat diet supplemented with white tea extract $(0.5 \%$, Obese + WTE group) for eight weeks.

\begin{tabular}{|c|c|c|}
\hline & Obese & Obese + WTE \\
\hline Triacylglycerol $\left(\mathrm{mmol} \cdot \mathrm{L}^{-1}\right)$ & $50.01 \pm 3.48$ & $41.54 \pm 2.29^{\star}$ \\
\hline Total Cholesterol (mmol.L $\left.\mathrm{L}^{-1}\right)$ & $2.88 \pm 0.10$ & $3.07 \pm 0.13$ \\
\hline HDL cholesterol (mmol.L $\left.\mathrm{L}^{-1}\right)$ & $2.22 \pm 0.05$ & $2.43 \pm 0.16$ \\
\hline Non-HDL cholesterol (mmol.L $\left.\mathrm{L}^{-1}\right)$ & $0.51 \pm 0.09$ & $0.41 \pm 0.08$ \\
\hline Total/HDL cholesterol & $1.23 \pm 0.04$ & $1.18 \pm 0.03$ \\
\hline Anti LDLox antibody (Arbitrary Unit) & $30.75 \pm 3.04$ & $29.00 \pm 4.62$ \\
\hline Conjugated Diene (Lag phase in min) & $12.00 \pm 1.92$ & $11.2 \pm 1.16$ \\
\hline Glycemia $\left(m m o l . L^{-1}\right)$ & $7.1 \pm 0.65$ & $8.33 \pm 0.86$ \\
\hline Oral glucose tolerance test (AUC) & $18106 \pm 1843$ & $15060 \pm 1830$ \\
\hline Insulin sensitivity test (AUC) & $1999 \pm 172$ & $2553 \pm 346$ \\
\hline
\end{tabular}

Student $\mathrm{t}$ test, values are mean \pm SEM. $\mathrm{n}=20$ animals per group; ${ }^{*} \mathrm{p}<0.05$. AUC: area under the curve.

\section{Discussion}

Epigallocatechin gallate (EGCG) is the main active compound of non-fermented tea from Camellia sinensis, and several studies have shown the beneficial properties of tea made from its plant (BOSE et al., 2008; LAMBERT et al., 2009; MAKI et al., 2009; NOMURA et al., 2008; PHUNG et al., 2010; TAKAMI et al., 2008; ZHENG et al., 2004). In the present study, it was found approximately $20 \%$ of EGCG in the white tea extract, which may have an important role in the beneficial effects of tea found in this study.

Firstly, we made sure that WTE was not hepatotoxic at the concentration used since Lambert (LAMBERT et al., 2009) reported the occurrence of liver damage when mice were supplemented with $1500 \mathrm{mg} \cdot \mathrm{kg}^{-1}$ weight of green tea extract, which was characterized by increased serum alanine aminotransferase concentration and moderate necrosis. Takami (TAKAMI et al., 2008) estimated that the maximum daily dose of green tea that does not cause adverse effects in rats was around $750 \mathrm{mg} \cdot \mathrm{kg}^{-1}$ body weight. These authors did not found changes in plasma GGT when doses of 0.3 to $5 \%$ extract of green tea were offered to rats compared to controls. In the present study, $0.5 \mathrm{~g}$ of white tea extract per $\mathrm{kg}$ of diet was offered, a similar dose to that tested by Takami (TAKAMI et al., 2008) using green tea. According to calculations based on the energy intake, this amount is equivalent to 3 cups/day of white tea for adult humans (BRUNO et al., 2008). Hence, a 5\% supplementation was used, which is safe dose.

Like green tea, white tea has been popularly used for weight loss in many countries. However, its weight loss potential has not been evaluated in controlled trials. In the present study, no effect of white tea extract was observed on the parameters related to reduction of body weight or adiposity, such as weight gain and final weight, visceral adiposity, and adipocyte area. Green tea has been claimed useful for weight gain and adiposity reduction (BRUNO et al., 2008; KIM et al., 2009; MAKI et al., 2009). Nagao (NAGAO; HASE; TOKIMITSU, 2007) hypothesized that the mechanism by which catechins reduce body fat may be related to the increase of energy expenditure. Dulloo (DULLOO et al., 1999) assumed that the increase of oxygen consumption and

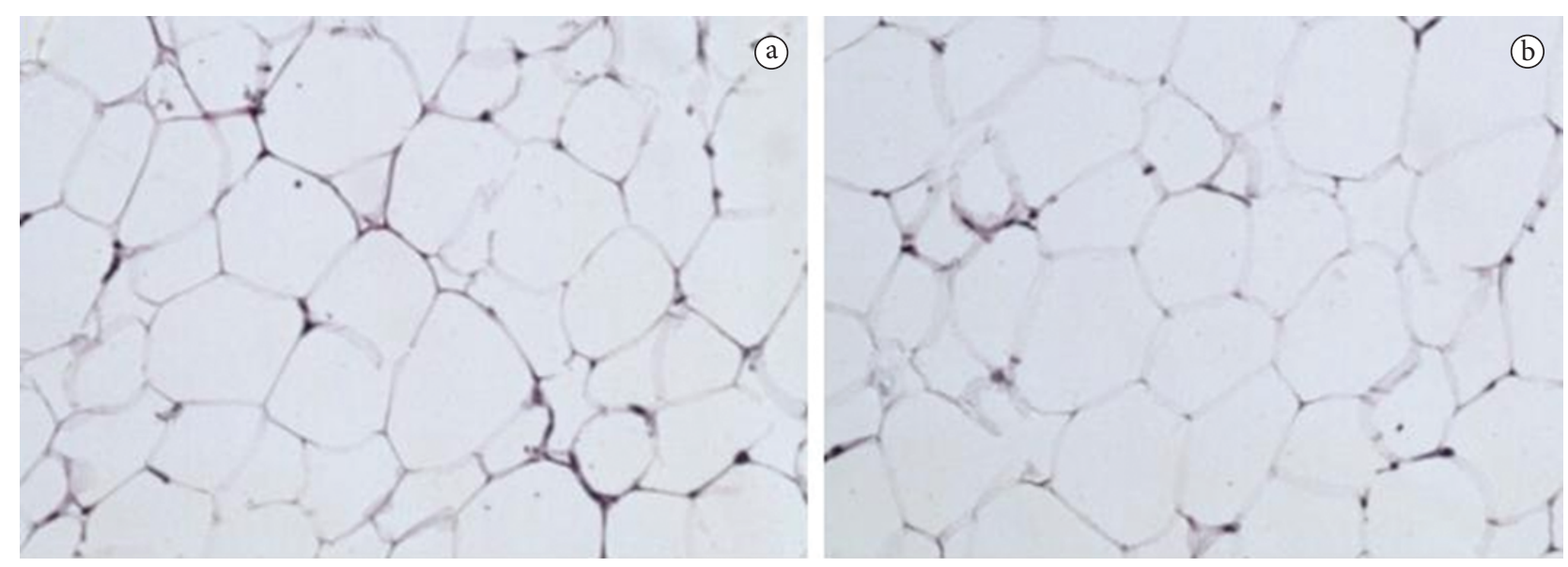

Figure 1. Histological analysis of epididymal adipose tissue of mice receiving high-fat diet (Obese group) (a) or high-fat diet supplemented with white tea extract (0.5\%, Obese + WTE group) (b) for eight weeks. Tissue stained with hematoxylin-eosin. Increased 100 times. 
Total lipids (liver)

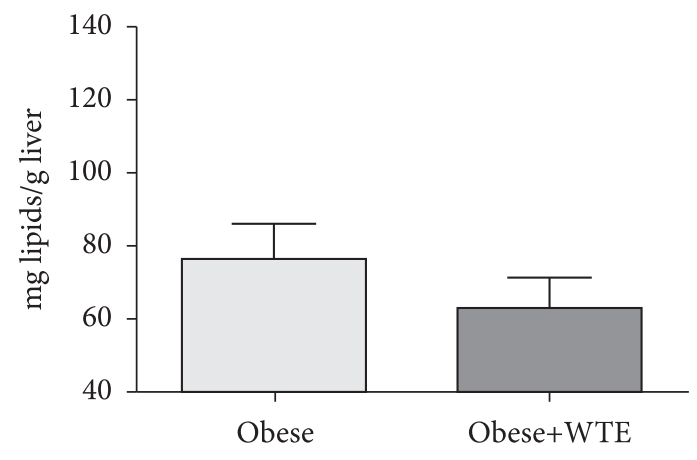

(C)

Triacylglycerols (cecum)

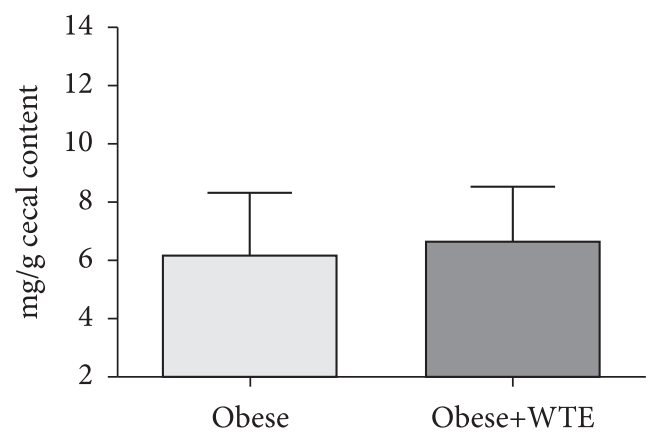

Total lipids (cecum)

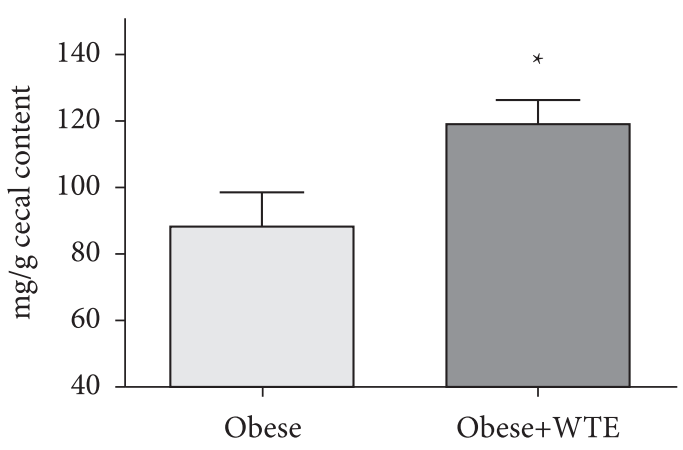

(d)

Cholesterol (cecum)

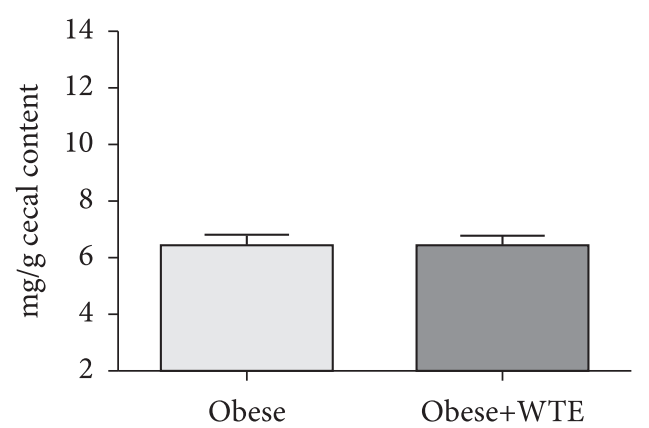

Lipids concentration in liver (a) and total lipids (b), triacylglycerols (c), and cholesterol (d) in cecal content of mice receiving high-fat diet (Obese group) or high-fat diet supplemented with white tea extract $(0.5 \%$, Obese + WTE group) for eight weeks. $n=8-10 /$ group Values are mean \pm SEM. Student $\mathrm{t}$ test ${ }^{*}=\mathrm{p}<0.05$.

the decrease of the respiratory quotient were due to sympathetic nerve-induced thermogenesis caused by the inhibition of catechol O-methyltransferase activity by green tea. Phung et al. (PHUNG et al., 2010) described mechanisms by which EGCG inhibits adipocyte differentiation and proliferation, reduces fat absorption, and increases energy and fat utilization. In the present study, it was observed a decrease in the total lipids absorption but not in TAG absorption. In conclusion, no sufficient evidences to support the use of white tea to reduce or control body weight were found.

Macrophage infiltration and activity in adipose tissue are important factors related to obesity and oxidative stress. In fact, there is no controlled study evaluating the effect of white or green tea on macrophage infiltration in adipose tissue. An indirect study was performed by Bose (BOSE et al., 2008) showing that epigallocatechin-3-gallate, the main polyphenol of green and white tea, was able to decrease serum monocyte chemoattractant protein 1 (MCP-1) concentration in mice fed high-fat diet. The authors also reported a decrease in mesenteric and retroperitoneal adipose tissue weight and suggested that this decrease may play a role in the effects of EGCG on high-fat-induced inflammation and the development of metabolic syndrome. Since MCP-1 is a major chemoattractive chemokine for macrophage, it could be assumed that its reduction is probably related to the reduction in macrophage migration to the site of MCP-1 production, such as adipose tissue. Nevertheless, the results obtained clearly show, by NAG activity as well as by the presence of crown like structures, that macrophage migration to perigonadal (visceral) adipose tissue was not affected by white tea intake.

However, white tea supplementation reduced serum triacylglycerols secondary to high-fat diet. Similar results were found by Richard et al. (2009), supplementing green tea to ob/ob mice, and Bose et al. (2008), studying epigallocatechin gallate in C57BL/6 mice. These authors also observed increased excretion of lipids after ingestion of a mixture of these teas. Although some studies have not shown the effect of catechins on the reduction of triacylglycerols (KIM et al., 2009; NAGAO; HASE; TOKIMITSU, 2007), the available literature on green tea and its catechins shows that it can improve the lipid profile by decreasing the luminal hydrolysis of lipids and thereby reduce its intestinal absorption (BABU; LIU, 2008; KOO; NOH, 2007). Furthermore, it has been reported that catechins regulate the expression of hepatic LDL receptors modulating the lipid synthesis, excretion, and intracellular processing (BABU; LIU, 2008; KOO; NOH, 2007). Since a higher concentration of lipids was found in the cecal content with no change in hepatic lipids of mice consuming white tea, it is suggested that the decrease in serum triacylglycerols may be due to decreased absorption 

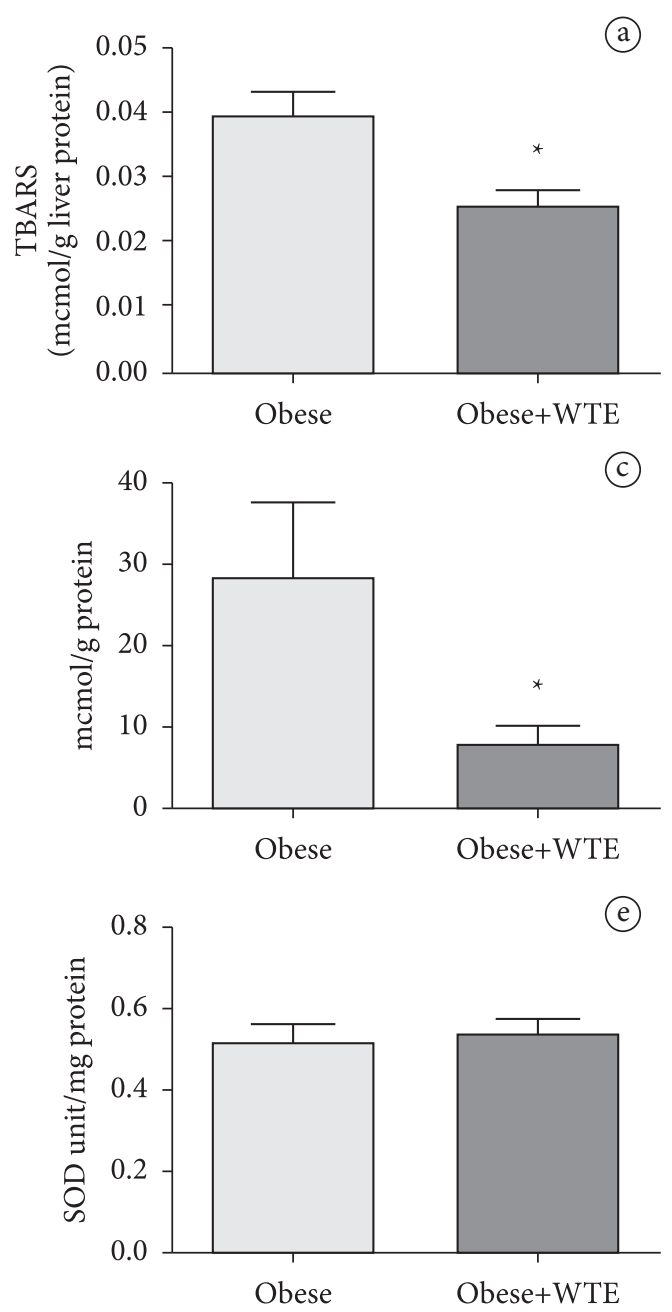
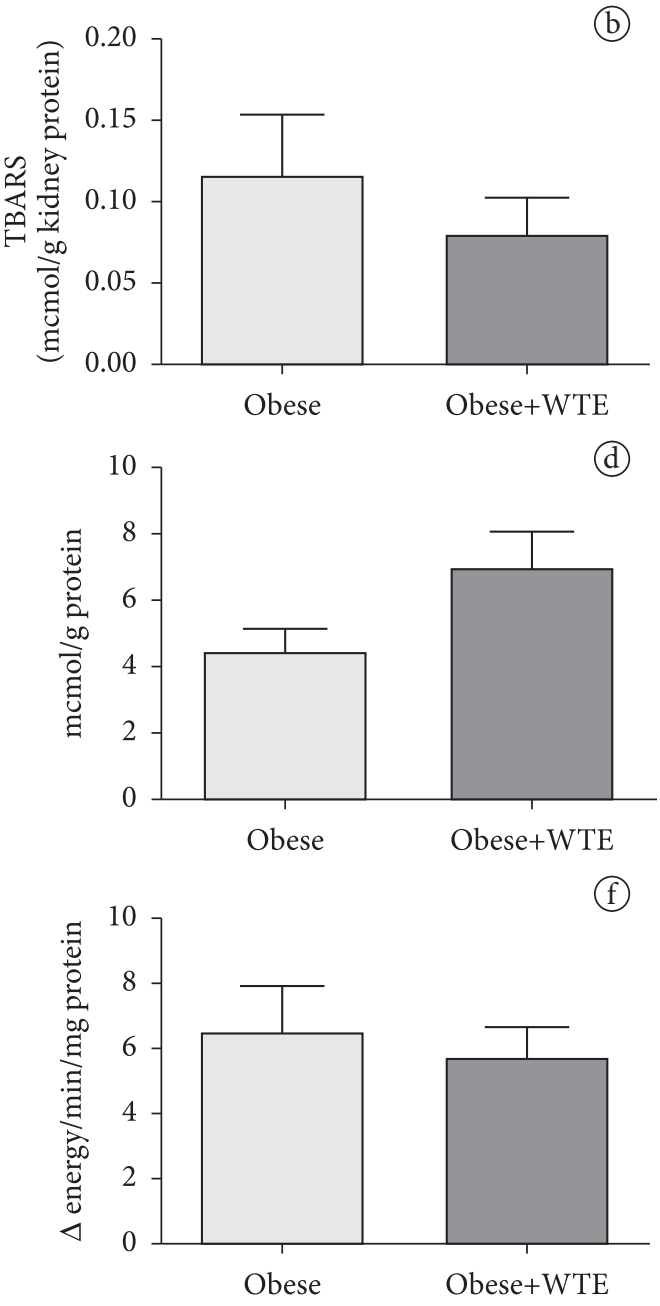

Figure 3. Thiobarbituric acid reactive substances (TBARS) and hyproperoxide in kidney (a and b, respectively) and liver (c and d, respectively), and activity of hepatic superoxide dismutase (e) and catalase (f) in mice receiving high-fat diet (Obese group) or high-fat diet supplemented with white tea extract $\left(0.5 \%\right.$, Obese + WTE group) for eight weeks. $n=8$ - 10 . Values are mean \pm SEM. Student $\mathrm{t}$ test, ${ }^{*} \mathrm{p}<0,05$.

rather than reduction in hepatic production or uptake of endogenous lipids.

Apart from blood triacylglycerols, no beneficial effect of white tea supplementation on cholesterol profile was observed. Studies with green tea are also controversial in this regard. Some authors found reduction of cholesterol in mice (KIM et al., 2009; RICHARD et al., 2009), while others did not find any difference (FARDET et al., 2008; ZHENG et al., 2004). The controversy also exists in clinical studies showing beneficial (HSU et al., 2008; NAGAO; HASE; TOKIMITSU, 2007) or no effect on blood cholesterol (MAKI et al., 2009) after green tea supplementation. Since antioxidant agents such as green and white tea do affect quantitatively the circulating lipoproteins and cholesterol, it is not surprising that they did not affect blood concentration of cholesterol. Instead, the actions of antioxidants are more qualitative reducing oxidation of LDL and activating macrophages; both crucial factors for the development of atherosclerosis.

Obesity is a well-known risk factor for insulin resistance. In this study, fasting glucose as well as insulin sensitivity and oral glucose tolerance test were similar in both groups, independently of white tea intake. This result is in agreement with most studies on glucose homeostasis (NOMURA et al., 2008; VENABLES et al., 2008) after green tea intake. In those studies, in which a beneficial effect of green tea in reducing glucose was observed, the amount of green tea in the diet was about $3 \%$, six times higher than that offered in the present study (KHAN et al., 2007), and the experimental period was 16 weeks, twice as much time of the present study (BOSE et al., 2008). In this regard, it seems unlikely that the lack of effect seen here was due to low dose or short time of experimentation. Nonetheless, clinical studies with active or inactive obese individuals did not support the action of green tea improving glucose homeostasis (HSU et al., 2008; MAKI et al., 2009).

Several studies have shown the antioxidant effect of white (ALMAJANO; VILA; GINES, 2011; CALZUOLA; GIANFRANCESCHI; MARSILI, 2006; KOUTELIDAKIS et al., 2009; KUMAR et al., 2012; SEERAM et al., 2008; THRING; HILI; NAUGHTON, 2009) and green tea (KHAN et al., 2007; KUMAR et al., 2012; PANZA et al., 2008). Since obesity caused by high-fat diet is also associated to the increase in oxidative 
stress due to the overload on mitochondrial respiratory chain, one of the objectives of this study was to observe whether the antioxidant effect of white tea was maintained even in the presence of the pro-oxidant stimulus induced by high-fat diet and obesity. The results obtained confirm the antioxidant properties attributed to this tea. White tea reduced oxidative stress in the liver and in the adipose tissue. This effect was not due to any change in the activity of antioxidant enzymes SOD and catalase, which remained unchanged after the use of this tea. This action could be associated with the presence of catechins, a major component of white tea that acts as direct or indirect antioxidant. Directly, catechins remove reactive oxygen and nitrogen species and chelates transition metal ions redox-active. Indirectly, they can inhibit redox-sensitive transcription factors; inhibit the synthesis of pro-oxidant enzymes, or activate the synthesis of antioxidant enzymes. SOD and catalase concentrations were not measured; their activities that were not affected by the WTE intake were measured. The results suggest that at least the direct antioxidant effect is maintained in a proxidant environment such as that caused by obesity.

The decrease in oxidative stress and circulating triacylglycerols may be protective against the development of obesity complications. Hypertriacylglycerolemia also leads to endothelial dysfunction contributing to atherogenesis (NADERALI et al., 2001). Moreover, the increased oxidative stress, itself, is a risk factor for cardiovascular diseases (VOGIATZI; TOUSOULIS; STEFANADIS, 2009). Since WTE reduces both serum triacylglycerol and oxidative stress, it could be assumed that this tea has also an atheroprotective effect. However, the C57BL/6 mice used in this study did not develop atherosclerosis and, therefore it cannot be affirmed that white tea is able to impair atherogenesis.

\section{Conclusion}

In conclusion, WTE $(0.5 \%)$ was not able to reduce body weight or adiposity in the experimental conditions. Nevertheless, white tea was able to reduce oxidative stress and circulating triacylglycerols even in a high pro-oxidative condition. These results highlight the potential beneficial effects of WTE on hypertriacylglycerolemia and other diseases related to increased oxidative stress rather than on obesity itself.

\section{Acknowledgements}

The authors are grateful to Maria Helena Alves Oliveira for the animal care assistance and to the Galgani Pharmacy for supplying white tea extract. CAPES (Coordination of Personal Improvement of Higher Education), CNPq (National Counsel of Technological and Scientific Development) and FAPEMIG (Foundation for Research Support of Minas Gerais).

\section{References}

AKAGIRI, S. et al. A Mouse Model of Metabolic Syndrome; Increase in Visceral Adipose Tissue Precedes the Development of Fatty Liver and Insulin Resistance in High-Fat Diet-Fed Male KK/Ta Mice. Journal of Clinical Biochemistry and Nutrition, v. 42, n. 2, p. 150-7, 2008. http://dx.doi.org/10.3164/jcbn.2008022
ALCAZAR, A. et al. Differentiation of green, white, black, Oolong, and $\mathrm{Pu}$-erh teas according to their free amino acids content. Journal of Agricultural and Food Chemistry, v. 55, n. 15, p. 5960-5, 2007. http://dx.doi.org/10.1021/jf070601a

ALMAJANO, M. P.; VILA, I.; GINES, S. Neuroprotective effects of white tea against oxidative stress-induced toxicity in striatal cells. Neurotoxicity Research, v. 20, n. 4, p. 372-8, 2011. http://dx.doi. org/10.1007/s12640-011-9252-0

ANGER, D. L.; PETRE, M. A.; CRANKSHAW, D. J. Heteroactivation of cytochrome P450 1A1 by teas and tea polyphenols. British Journal of Pharmacology, v. 145, n. 7, p. 926-33, 2005. http://dx.doi. org/10.1038/sj.bjp.0706255

BABU, P. V.; LIU, D. Green tea catechins and cardiovascular health: an update. Current Medicinal Chemistry, v. 15, n. 18, p. 184050, 2008. http://dx.doi.org/10.2174/092986708785132979

BAILEY, P. J. Sponge implants as models. Methods in Enzymology, v. 162 , p. $327-34,1988$. http://dx.doi.org/10.1016/00766879(88)62087-8

BANERJEE, D. et al. Determination of absolute hydrogen peroxide concentration by spectrophotometric method. Current Science, v. 83, n. 10, p. 1193-1194, 2002.

BOSE, M. et al.The major green tea polyphenol, (-)-epigallocatechin3 -gallate, inhibits obesity, metabolic syndrome, and fatty liver disease in high-fat-fed mice. Journal of Nutrition, v. 138, n. 9 , p. 1677-83, 2008.

BRUNO, R. S. et al. Green tea extract protects leptin-deficient, spontaneously obese mice from hepatic steatosis and injury. Journal of Nutrition, v. 138, n. 2, p. 323-31, 2008.

CALZUOLA, I.; GIANFRANCESCHI, G. L.; MARSILI, V. Comparative activity of antioxidants from wheat sprouts, Morinda citrifolia, fermented papaya and white tea. International Journal of Food Sciences and Nutrition, v. 57, n. 3-4, p. 168-77, 2006. http://dx.doi. org/10.1080/09637480600658328

CHUNG, B. H. et al. Single vertical spin density gradient ultracentrifugation. Methods in Enzymology, v. 128, p. 181-209, 1986. http://dx.doi.org/10.1016/0076-6879(86)28068-4

DIETERICH, S. et al. Gene expression of antioxidative enzymes in the human heart: increased expression of catalase in the end-stage failing heart. Circulation, v. 101, n. 1, p. 33-9, 2000. http://dx.doi. org/10.1161/01.CIR.101.1.33

DULLOO, A. G. et al. Efficacy of a green tea extract rich in catechin polyphenols and caffeine in increasing 24-h energy expenditure and fat oxidation in humans. The American Journal of Clinical Nutrition, v. 70, n. 6, p. 1040-5, 1999.

FARDET, A. et al. A liquid chromatography-quadrupole time-of-flight (LC-QTOF)-based metabolomic approach reveals new metabolic effects of catechin in rats fed high-fat diets. Journal of Proteome Research, v. 7, n. 6, p. 2388-98, 2008. http://dx.doi.org/10.1021/ pr800034h

FAZIO, S. et al. Increased atherosclerosis in mice reconstituted with apolipoprotein E null macrophages. Proceedings of the National Academy of Sciences of the United States of America, v. 94, n. 9, p. 4647-52, 1997. http://dx.doi.org/10.1073/pnas.94.9.4647

FOLCH, J. L. M.; STANLEY, G. H. S. A simple method for the isolation and purification of total lipídeos from animal tissues. The Journal of Biological Chemistry, v. 226, p. 497-509, 1957.

FURUKAWA, S. et al. Increased oxidative stress in obesity and its impact on metabolic syndrome. The Journal of Clinical Investigation, v. 114, n. 12, p. 1752-61, 2004. 
GIESEG, S. P.; ESTERBAUER, H. Low density lipoprotein is saturable by pro-oxidant copper. FEBS Letters, v. 343, n. 3, p. 188-94, 1994. http://dx.doi.org/10.1016/0014-5793(94)80553-9

HSU, C. H. et al. Effect of green tea extract on obese women: a randomized, double-blind, placebo-controlled clinical trial. Clinical Nutrition, v. 27, n. 3, p. 363-70, 2008. http://dx.doi.org/10.1016/j. clnu.2008.03.007

KHAN, S. A. et al. Influence of green tea on enzymes of carbohydrate metabolism, antioxidant defense, and plasma membrane in rat tissues. Nutrition, v. 23, n. 9, p. 687-95, 2007. http://dx.doi. org/10.1016/j.nut.2007.06.007

KIM, H. J. et al. Antilipogenic effect of green tea extract in C57BL/6J-Lep ob/ob mice. Phytotherapy Research, v. 23, n. 4, p. 467-71, 2009. http://dx.doi.org/10.1002/ptr.2647

KOO, S. I.; NOH, S. K. Green tea as inhibitor of the intestinal absorption of lipids: potential mechanism for its lipid-lowering effect. The Journal of Nutritional Biochemistry, v. 18, n. 3, p. 179-83, 2007. http://dx.doi.org/10.1016/j.jnutbio.2006.12.005

KOUTELIDAKIS, A. E. et al. Green tea, white tea, and Pelargonium purpureum increase the antioxidant capacity of plasma and some organs in mice. Nutrition, v. 25, n. 4, p. 453-8, 2009. http://dx.doi. org/10.1016/j.nut.2008.10.007

KUMAR, M. et al. Protective effects of green and white tea against benzo(a)pyrene induced oxidative stress and DNA damage in murine model. Nutrition and Cancer, v. 64, n. 2, p. 300-6, 2012. http://dx.doi.org/10.1080/01635581.2012.648300

LAMBERT, J. D. et al. Hepatotoxicity of high oral dose (-)-epigallocatechin-3-gallate in mice. Food and Chemical Toxicology, v. 48, n. 1, p. 409-416, 2009. http://dx.doi.org/10.1016/j. fct.2009.10.030

LOPEZ, V.; CALVO, M. I. White tea (Camellia sinensis Kuntze) exerts neuroprotection against hydrogen peroxide-induced toxicity in PC12 cells. Plant Foods for Human Nutrition, v. 66, n. 1, p. 22-6, 2011. http://dx.doi.org/10.1007/s11130-010-0203-3

LOWRY, O. H. et al. Protein measurement with the Folin phenol reagent. The Journal of Biological Chemistry, v. 193, n. 1, p. 265-75, 1951.

MAKI, K. C. et al. Green tea catechin consumption enhances exerciseinduced abdominal fat loss in overweight and obese adults. Journal of Nutrition, v. 139, n. 2, p. 264-70, 2009. http://dx.doi.org/10.3945/ jn.108.098293

MALINOWSKA, E. et al. Assessment of fluoride concentration and daily intake by human from tea and herbal infusions. Food and Chemical Toxicology, v. 46, n. 3, p. 1055-61, 2008. http://dx.doi. org/10.1016/j.fct.2007.10.039

NADERALI, E. K. et al. Dietary obesity in the rat induces endothelial dysfunction without causing insulin resistance: a possible role for triacylglycerols. Clinical Science, v. 101, n. 5, p. 499-506, 2001. http://dx.doi.org/10.1042/CS20010088

NAGAO, T.; HASE, T.; TOKIMITSU, I. A green tea extract high in catechins reduces body fat and cardiovascular risks in humans. Obesity (Silver Spring), v. 15, n. 6, p. 1473-83, 2007. http://dx.doi. org/10.1038/oby.2007.176

NARVANEN, O.; ERKKILA, A.; YLA-HERTTUALA, S. Evaluation and characterization of EIA measuring autoantibodies against oxidized LDL. Free Radical Biology \& Medicine, v. 31, n. 6, p. 769-77, 2001. http://dx.doi.org/10.1016/S0891-5849(01)00636-0

NASCIMENTO, A., CASTILHO, R. O.; VIANNA-SOARES, C. D. Método extrativo-analítico para determinação de taninos em insumos e produtos vegetais. BR patent. 14090003895. 14 ago. 2009.

NELSON, D. P.; KIESOW, L. A. Enthalpy of decomposition of hydrogen peroxide by catalase at 25 degrees $C$ (with molar extinction coefficients of $\mathrm{H} 2 \mathrm{O} 2$ solutions in the UV). Analytical Biochemistry, v. 49 , n. 2, p. 474-8, 1972. http://dx.doi.org/10.1016/00032697(72)90451-4

NOMURA, S. et al. Tea catechins enhance the mRNA expression of uncoupling protein 1 in rat brown adipose tissue. The Journal of Nutritional Biochemistry, v. 19, n. 12, p. 840-7, 2008. http://dx.doi. org/10.1016/j.jnutbio.2007.11.005

PANZA, V. S. et al. Consumption of green tea favorably affects oxidative stress markers in weight-trained men. Nutrition, v. 24, n. 5, p. 433-42, 2008. http://dx.doi.org/10.1016/j.nut.2008.01.009

PARK, J.; CHUNG, J. J.; KIM, J. B. New evaluations of redox regulating system in adipose tissue of obesity. Diabetes Research and Clinical Practice, v. 77, p. S11-6, 2007. Supplement 1.

PEREZ-JIMENEZ, A. et al. The effect of dietary methionine and white tea on oxidative status of gilthead sea bream (Sparus aurata). British Journal of Nutrition, p. 1-8, 2011. http://dx.doi.org/10.1017/ S0007114511006556

PEREZ-JIMENEZ, A. et al. The effect of hypoxia on intermediary metabolism and oxidative status in gilthead sea bream (Sparus aurata) fed on diets supplemented with methionine and white tea. Comparative Biochemistry and Physiology Part C: Toxicology \& Pharmacology, v. 155 , n. 3, p. 506-16, 2012. http://dx.doi. org/10.1016/j.cbpc.2011.12.005

PHUNG, O. J. et al. Effect of green tea catechins with or without caffeine on anthropometric measures: a systematic review and metaanalysis. The American Journal of Clinical Nutrition, v. 91, n. 1, p. 73-81, 2010. http://dx.doi.org/10.3945/ajcn.2009.28157

PINCHUK, I.; LICHTENBERG, D. The mechanism of action of antioxidants against lipoprotein peroxidation, evaluation based on kinetic experiments. Progress in Lipid Research, v. 41, n. 4, p. 279-314, 2002. http://dx.doi.org/10.1016/S0163-7827(01)00026-1

RICHARD, D. et al. Weight and plasma lipid control by decaffeinated green tea. Pharmacological Research, v. 59, n. 5, p. 351-4, 2009. http://dx.doi.org/10.1016/j.phrs.2009.01.015

SANTOS, S. H. et al. Mas deficiency in FVB/N mice produces marked changes in lipid and glycemic metabolism. Diabetes, v. 57, n. 2, p. 340-7, 2008. http://dx.doi.org/10.2337/db07-0953

SCHNITZER, E. et al. Lipid oxidation in unfractionated serum and plasma. Chemistry and Physics of Lipids, v. 92, n. 2, p. 151-70, 1998. http://dx.doi.org/10.1016/S0009-3084(98)00021-8

SEERAM, N. P. et al. Comparison of antioxidant potency of commonly consumed polyphenol-rich beverages in the United States. Journal of Agricultural and Food Chemistry, v. 56, n. 4, p. 1415-22, 2008. http://dx.doi.org/10.1021/jf073035s

TAKAMI, S. et al. Evaluation of toxicity of green tea catechins with 90-day dietary administration to F344 rats. Food and Chemical Toxicology, v. 46, n. 6, p. 2224-9, 2008. http://dx.doi. org/10.1016/j.fct.2008.02.023

THRING, T. S.; HILI, P.; NAUGHTON, D. P. Anti-collagenase, antielastase and anti-oxidant activities of extracts from 21 plants. BMC Complementary and Alternative Medicine, v. 9, n. p. 27, 2009.

THRING, T. S.; HILI, P.; NAUGHTON, D. P. Antioxidant and potential anti-inflammatory activity of extracts and formulations of white tea, rose, and witch hazel on primary human dermal fibroblast cells. Journal of Inflammation, v. 8, n. 1, p. 27, 2011. http://dx.doi. org/10.1186/1476-9255-8-27 
UNACHUKWU, U. J. et al. White and green teas (Camellia sinensis var. sinensis): variation in phenolic, methylxanthine, and antioxidant profiles. Journal of Food Science, v. 75, n. 6, p. C541-8, 2010. http:// dx.doi.org/10.1111/j.1750-3841.2010.01705.x

VAN DER HOOFT, J. J. et al. Structural Annotation and Elucidation of Conjugated Phenolic Compounds in Black, Green, and White Tea Extracts. Journal of Agricultural and Food Chemistry, 2012. http://dx.doi.org/10.1021/jf300297y

VAY, D. et al. Circulating antibodies recognizing malondialdehydemodified proteins in healthy subjects. Free Radical Biology \& Medicine, v. 30, n. 3, p. 277-86, 2001. http://dx.doi.org/10.1016/ S0891-5849(00)00469-X

VENABLES, M. C. et al. Green tea extract ingestion, fat oxidation, and glucose tolerance in healthy humans. The American Journal of Clinical Nutrition, v. 87, n. 3, p. 778-84, 2008.
VOGIATZI, G.; TOUSOULIS, D.; STEFANADIS, C. The role of oxidative stress in atherosclerosis. The Hellenic Journal of Cardiology, v. 50, n. 5, p. 402-9, 2009.

WALLIN, B. et al. Lipoprotein oxidation and measurement of thiobarbituric acid reacting substances formation in a single microtiter plate: its use for evaluation of antioxidants. Analytical Biochemistry, v. 208, n. 1, p. 10-5, 1993. http://dx.doi.org/10.1006/ abio.1993.1002

WANG, R. et al. Protective versus promotional effects of white tea and caffeine on PhIP-induced tumorigenesis and beta-catenin expression in the rat. Carcinogenesis, v. 29, n. 4, p. 834-9, 2008. http://dx.doi.org/10.1093/carcin/bgn051

ZHENG, G. et al. Anti-obesity effects of three major components of green tea, catechins, caffeine and theanine, in mice. In Vivo, v. 18, n. 1, p. $55-62,2004$. 